This item was submitted to Loughborough's Research Repository by the author.

Items in Figshare are protected by copyright, with all rights reserved, unless otherwise indicated.

\title{
Fostering sustainability in infrastructure development schemes
}

PLEASE CITE THE PUBLISHED VERSION

http://www.sustainabilityjournal.com

\section{PUBLISHER}

(c) Institution of Civil Engineers

VERSION

VoR (Version of Record)

LICENCE

CC BY-NC-ND 4.0

REPOSITORY RECORD

Willetts, Richard, Jim Burdon, Jacqueline Glass, and Matthew W. Frost. 2019. "Fostering Sustainability in Infrastructure Development Schemes”. figshare. https://hdl.handle.net/2134/11631. 
This item was submitted to Loughborough's Institutional Repository (https://dspace.lboro.ac.uk/) by the author and is made available under the following Creative Commons Licence conditions.

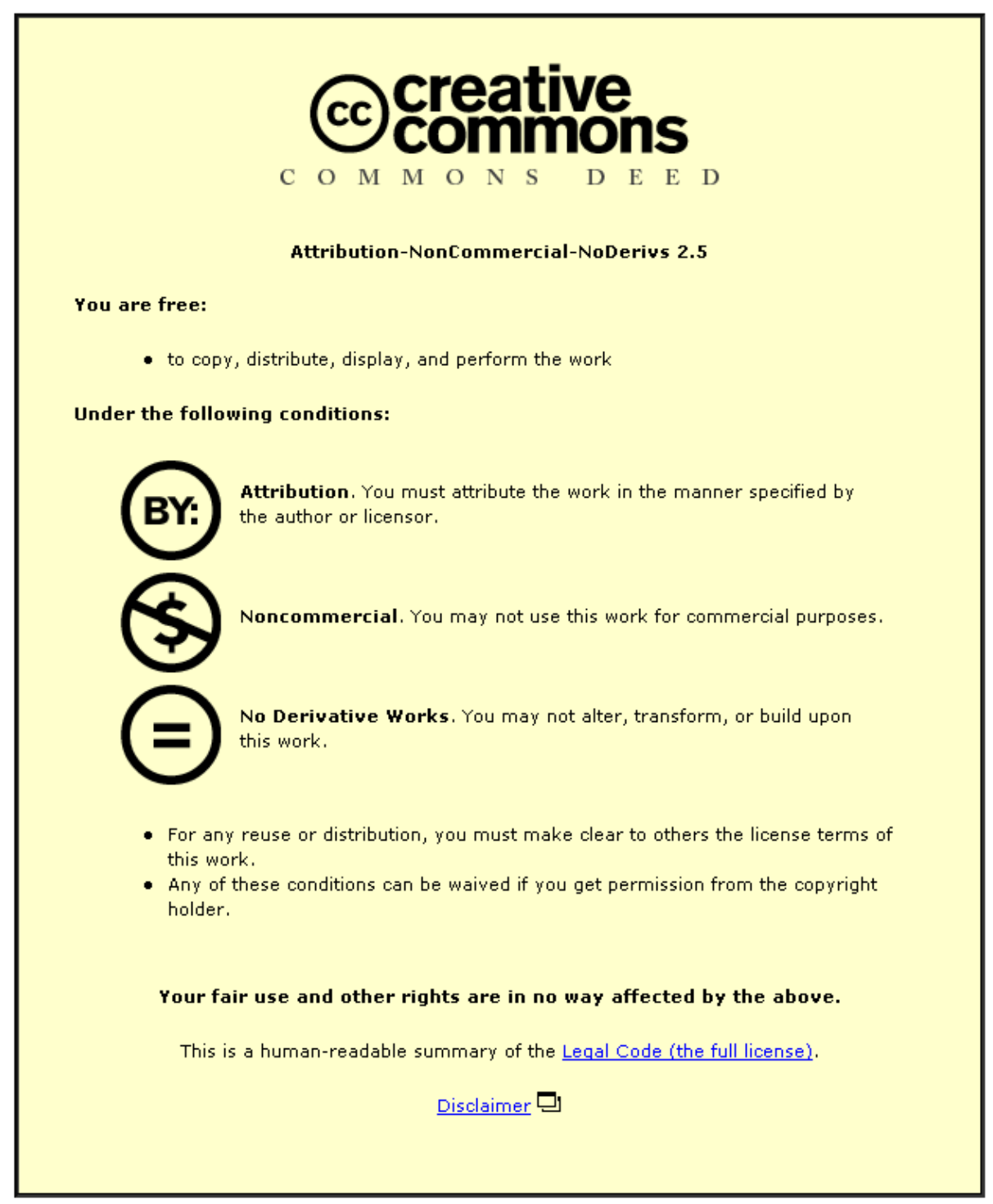

For the full text of this licence, please go to: http://creativecommons.org/licenses/by-nc-nd/2.5/ 
Richard Willetts Research Enginee Jacobs Engineering Nottingham, UK
Matthew Frost Lecturer, Department of Civil and Building Engineering, Loughborough University, Loughborough, UK

\section{Fostering sustainability in infrastructure development schemes}

R. Willetts MEng, J. Burdon BEng, J. Glass PhD, DipArch, DipBRS, CertHE and M. Frost PhD, PgCHE

In recent years much emphasis has been placed upon meeting the environmental and socioeconomic aims of sustainable development. This is being driven by government policy and industry initiatives, with the main emphasis placed on the building sector, where it is perceived that most benefits can be gained. Although financial incentives and drivers are perhaps more readily quantifiable in this market, the potential to mitigate the negative environmental and socioeconomic impacts associated with the development of infrastructure such as roads, drainage and utilities at a neighbourhood scale may be no less significant, if more difficult to measure. Despite this, relatively little attention has been paid to the sustainable design of infrastructure. In addition, change to the UK planning system has been identified as a key mechanism to deliver sustainability policy, but there appears to be a poor connection between planning policy and infrastructure implementation practices. Sustainable construction, planning policy and the notion of the engineer's role in sustainable infrastructure are explored in this paper, which concludes by presenting four areas where improved dialogue between stakeholders and enhancement of the engineer's role at an early stage could improve sustainability in infrastructure development projects.

\section{INTRODUCTION}

Sustainable development has been on the political horizon for 20 years but only in the last decade has it begun to be enshrined in the political system. Sustainability is generally considered to involve the protection of the environment and resources while ensuring economic equity and social inclusion.

The construction industry is one of the largest sectors in the UK providing work for $2 \cdot 1$ million people, generating nearly $10 \%$ of gross domestic product. Throughout its construction, operation and maintenance, the built environment contributes nearly 50\% of all carbon emissions, 33\% of landfill waste, and consumes $13 \%$ of raw materials and 50\% of water (DBERR, 2007; DTI, 2006). These figures show clearly why the sector needs to be a leader in embracing sustainability to minimise its detrimental impact and mitigate negative impacts on future generations. While much progress has been made in some areas such as building design, waste and procurement, there is still much room for improvement. Civil engineering and the development of infrastructure is one of the areas that seems to have attracted little direct attention. This involves the delivery of key transport infrastructure, utilities and services, so it is essential that engineers are aware of the principles behind sustainable development and the ways in which they can help. Engineers will need to work more closely with planners and the planning policy that has been devised to deliver sustainable development (ODPM, 2005a) at both the national and local level.

This paper sets out to review the nature of sustainable development of infrastructure projects, by first setting out the policy context in the UK in terms of sustainable construction and planning. It then attempts to characterise what is meant by sustainable infrastructure, followed by an analysis of how well or otherwise the currently available assessment methods for construction projects address key sustainability issues in UK policy. The paper concludes with a call for a unified conversation about the delivery of sustainability in infrastructure projects.

\section{SUSTAINABLE DEVELOPMENT STRATEGY: FROM THEORY TO APPLICATION}

'Sustainability' is a term that is used widely and interchangeably throughout all sectors and has any number of meanings to the individual or group depending upon context and understanding (Adetunji and CICE, 2006). The Brundtland Report (WCED and Brundtland, 1987) identified the importance of environmental protection and the social importance of not depriving other citizens and future generations, underlying principles that have been built upon and adapted in several notable models that have split the idea of sustainable development into three areas: environmental protection, social equity and economic prosperity. The most notable of these was created by Elkington (1994) who attempted to look not just at potential economic gains but also at positive or negative social and environmental impacts that their actions may have, emphasising the importance of corporate responsibility. This is often referred to as the triple bottom line or three pillars, which place equal emphasis on balancing all three components. The UK's first strategy on sustainable development was issued in 1994 and set out the government's general principles, objectives and approach to environmental issues (DOE, 1994). The UK strategy has been continually updated and the current version (DETR, 2005) sets out four priority areas: sustainable consumption and production; climate change and energy; natural resource protection and environmental enhancement; and sustainable communities. 
Although the government has been looking at ways to address sustainable development since the early 1990s, it is only since 2000 that it has turned its attention to the construction industry (Rydin et al., 2006). Construction is recognised as being of major importance to the successful delivery of the UK sustainable development agenda (DETR, 2000). It clearly affects the delivery of all four priority areas of the UK's sustainable development strategy (DETR, 2005) and underpins many of the 68 headline indicators, such as carbon dioxide emissions, aggregate extraction, water resource use, waste created by construction and demolition, land use, productivity and road freight. Manie (2007) believes that the construction sector is unique because it can touch upon the majority of the sustainability agenda; it can influence both short-term (construction) and medium to longterm (maintenance and use) goals. The main purpose of sustainable construction is to apply the principles of sustainable development: conserving present resources for the benefit of future generations to the construction sector (Kibert, 2007). This definition, though, and many others, struggle to grapple with the scale and fuzzy boundaries of the sector, which can range from material extraction, product manufacture, transportation, demolition, building services as well as design and even urban planning (Kibert, 2007; Rydin et al., 2006). In fact, the majority of definitions focus on environmental aspects, but fail to capture the more holistic nature of sustainability. In addition, there is the need to define not only the actual construction process, but also pre-construction (planning and urban design) and postconstruction (maintenance, operation and deconstruction) in a more cross-cutting way (Hill and Bowen, 1997; Rydin et al., 2006; Shah, 2007). The notion of a 'cradle to grave', life-cycle approach is more commonly being seen as an essential principle (Bjorn et al., 2005; Hill and Bowen, 1997; Mirza, 2006; Wyatt, 1994). In response, much of the literature now forms a consensus on what sustainable construction should involve, both in terms of its place within a sustainable development agenda and within the industry itself. Table 1 provides a summary of the key themes associated with sustainable construction.

All that said, legislation is now seen as the main driver for sustainability in the built environment (CIBSE, 2007a). In 2008, the Department of Business, Enterprise and Regulatory Reform (DBERR) released its 'strategy for sustainable construction' which aims 'to provide a catalyst to achieve a step change in sustainability of the procurement, design, construction and operation of all built assets'; this built upon the DETR strategy (2000) and research into improvements in the industry (DTI, 2006). The DBERR strategy was developed within the context of four principles set out in Securing the Future (DETR, 2005) and Rethinking Construction (Egan, 1998; which is still seen as industry's principal driver for change). The strategy also has a crossover with The Egan Review (Egan, 2004), which reviewed the skills needed for industry workers to meet the sustainable communities' agenda (ODPM, 2003). The DBERR strategy does not aim to act as new legislation but tackles the gaps in existing legislation to provide a more sustainable built environment (DBERR, 2007), through

(a) procurement: integrated teams and supply chains to carry out 50\% of projects by value by the end of 2007 and complete review of public procurement strategy

(b) design: Breeam 'excellent' standards for all new build on government estate, greater industry take-up of design quality indicators

(c) innovation: increase in industry undertaking innovative work and uptake of EU schemes

(d) the people agenda: tougher targets for the reduction of health and safety incidents and increased staff training and retention.

(e) Better regulation and business support simplification.

In addition, four key areas are to be improved

(a) climate change: all new homes zero carbon by 2016, increased energy efficiency across the board

(b) water: reduced consumption across the sector and consultation on adoption of sustainable urban drainage systems

(c) biodiversity: aim to maintain and increase biodiversity

(d) waste and materials: zero waste to landfill by 2020 and greater use of 'green' materials.

One notable omission from the DBERR document is planning, energy and infrastructure. The first two are excluded because they are being reviewed and legislated sufficiently (see next section) and infrastructure because it is believed that the civil engineering sector is developing its own strategy (DBERR, 2007). However, several industry bodies (e.g. CIC, 2007; CIOB, 2007; QPA, 2007) have voiced concern that the omission of civil engineering is far from desirable and will not lead to a holistic, joined-up solution. This is reinforced by Rydin et al. (2006) who observed that the industry will try to fill the smallest possible definition of sustainable development, rather than aim to place itself at the centre of creating a sustainable built environment, which is a theme that will be explored throughout this paper.

\section{SUSTAINABILITY IN PLANNING}

In addition to considering sustainable construction, the scale of civil engineering projects necessitates some discussion of the UK planning policy context. Planning aims to set out the most

\begin{tabular}{|lll|}
\hline Social & Economic & Environmental \\
\hline Health and safety & Procurement & Resource consumption \\
Communities & Supply chain & Energy efficiency \\
Skills & Profitability & Waste \\
$\begin{array}{l}\text { Stakeholder satisfaction } \\
\text { Inclusiveness }\end{array}$ & Competitiveness & Climate change \\
& Growth & Water consumption \\
& & Biodiversity and habitat \\
& & Land use \\
Table I. Key sustainable construction themes & (Adetunji, 2006; DBERR, 2007; DTI, 2006; Hill and Bowen, 1997; Kibert, 2007; Parkin et \\
\hline al., 2003; Pearce, 2006; Rydin et al., 2006) & & \\
\hline
\end{tabular}


appropriate use of collective space and is implemented at a national, regional and local level to maximise its impact and potential for success along with delivering environmental and social justice (Gunder, 2006; Prior and Williams, 2008). The UK government has committed itself to the promotion of sustainable development through the planning process and urban design principles: '... sustainable development is the core principle underpinning planning.' (ODPM, 2005a). The 2004 Planning and Compulsory Purchase Act, which is replacing previous arrangements under the Town and County Planning Act 1990, aimed to make the planning process simpler, faster and more inclusive for local communities. It set in place regional spatial strategies with the aim of establishing regional objectives for development, in particular relating to employment and transport needs but also housing requirements (English Partnerships, 2006). In section 39 of the Act it also sets in place for local authorities with regard to regional spatial strategies and local development documents to '... exercise the function with the objective of contributing to the achievement of sustainable development' (Planning and Compulsory Purchase Act, 2004).

These aims are delivered through local development frameworks, consisting of, for example, a statement of community involvement, supplementary planning documents and area action plans (DTI and Faber Maunsell, 2008). The Planning and Compulsory Purchase Act (2004) also made it a requirement that all regional spatial strategies and local development documents (DPD) receive a sustainability appraisal in line with the European strategic environmental assessment directive (Directive 2001/42/EC), which aims to ensure that environmental, social and economic considerations are taken into account in the preparation of strategic documents (ODPM, 2005b). The Planning Act (2008) built upon 'Planning for a sustainable future: white paper', which itself built on two major government commissioned reports (the Barker Review of Land Use Planning (DCLG, 2006), which called for a more responsive, less bureaucratic and streamlined planning system and the Eddington Transport Study (DfT, 2006), which highlighted the need for reform on major infrastructure projects and greater clarity on government policy]. Several elements of the Planning Act came into force in April 2009, including the removal of the need for a sustainability appraisal of supplementary planning documents and the introduction of a community infrastructure levy to allow councils to raise funds to support infrastructure needed for growing communities more easily.

It is the Department for Communities and Local Government (DCLG) that oversees the implementation of a number of statutory guidance documents relating to planning that include planning policy guidance and planning statements, which will eventually supersede planning policy guidelines. These set out the policy, together with guidance for local authorities when devising local plans and making planning decisions. Of these, PPS1: 'Delivering sustainable development' and its supplement 'Planning and climate change', covering resilience to the effects of climate change and promoting sustainable energy, transport and growth are the most relevant, underpinning all others. It calls on planning bodies to identify potential locations for decentralised power generation and the integration of climate change considerations. It encourages local authorities to embrace innovation and sustainable construction (DCLG, 2007a). Cooper (2006) suggests, however, that a lack of government regulation has led to local planning authorities producing their own supplementary planning documents with an emphasis on the environmental performance of buildings. This has resulted in a 'post code' lottery for developers (Cooper, 2006), with some avoiding areas with onerous guidelines, which could have time and financial impacts on the profitability of all development. Further concerns that have been raised regarding recent planning policy changes are, that: much of the theory is poorly researched and planning has a limited effect on behavioural change (Williams, 2006); the Barker review was incorrect in that it assumed the role of planning policy was to deliver economic growth (Campaign to Protect Rural England, 2007); the influence of sustainability appraisal at the regional level is slight as a result of it being unclear how sustainability appraisal can influence policy (Levett-Therivel, 2007); and at the regional level there is more concern for sustainability appraisal being legally compliant than effective (SDRN, 2008).

Finally, within both the building regulations and planning policy much emphasis has been placed on delivering energyefficient homes and buildings, leading to reductions in carbon dioxide, while increasing housing supply. However, little attention is paid to the infrastructure that serves the development (namely roads, utilities and drainage etc.).

\section{SUSTAINABILITY IN INFRASTRUCTURE}

Changes to planning policy and the development of government strategy on sustainable development and construction have resulted in a clear emphasis on the development of efficient, low-energy 'green buildings' and assessment techniques for energy and resource use, indoor environmental quality and ecological loadings (Cole, 2005; Kaatz et al., 2006). Resulting advances in sustainable construction can and will have some influence on the development of more sustainable infrastructure, but to date there has been far less attention paid to the 'greening' of infrastructure (Huang and Yeh, 2008). Unlike buildings and facilities, infrastructure displays less obvious ongoing costs: there are fewer, less frequent bills to be paid and so it can be harder to demonstrate that savings can be made. Despite the possible deterioration of a piece of infrastructure and subsequent increased costs in its maintenance, plus the environmental and social impacts, little is done by infrastructure operators to seek innovative solutions in operation or in procuring new projects (Hartshorn et al., 2005). Possible reasons for this include a perceived increase in potential costs, risks and fear of the untested or untried (Hartshorn et al., 2005; Roberts and Sims, 2007). The lack of attention to infrastructure is particularly surprising given that highways, drainage systems and utilities supply all have a major impact on the priority areas for national sustainable development (Chandler et al., 2008; Forman and Alexander, 1998; Lin, 2005), for example through: the consumption of large quantities of primary and secondary construction materials and generation of waste; some of the most heavily consumed materials, cement and asphalt, requiring large amounts of energy in their production and transportation leading to significant greenhouse gas emissions; depletion of natural resources leading to environmental degradation along with loss of natural habitats and major impacts (visual,

increased noise, increased emissions, loss of habitat, etc.); and, incorrectly specified infrastructure failing to support the 
behavioural changes required to deliver sustainable communities and transport.

For the infrastructure sector to realise its potential to drive change though will require a shift away from the traditional project objectives of cost, time and quality, which are used as the current paradigm through which we view a project, define the problem space and develop solutions that are suitable to meet these three needs (Fenner et al., 2006; Gambatese and Rajendran, 2005). Various work has started to examine the wider issues that should be considered in infrastructure delivery but much of this has been restricted to a narrow part of the sustainable development agenda. The main emphasis has been on environmental issues, but even more so, has focused mainly on recycling and reuse of materials, waste reduction and energy efficiency in infrastructure construction and maintenance. These three areas are important in tackling resource use, but cannot alone deliver a sustainable project. That said, it is encouraging that these practices are becoming more mainstream; first on the policy side, with local authorities setting minimum targets for materials such as recycled aggregates and waste to landfill in their supplementary planning documents, and second, on the supply side where take-up is also widespread among contractors who have found economic benefits through reduced landfill costs and reduced need for primary materials. On a broader scale, however, various research studies (e.g. Lim and Yang, 2006; Sahely et al., 2005; Ugwu and Haupt, 2005) have attempted to identify the scope of sustainable infrastructure and relevant indicators and how these relate to the delivery process. A selection of recurring themes can be identified and a conceptual framework identified by Lim and Yang (2006) is shown in Figure 1, which shows clearly the vast range of issues associated with the delivery of a sustainable infrastructure project.

Given that such a wide range of issues should be encompassed within sustainable infrastructure, it is understandable that a significant body of research is developing related to tools and assessment methods that are said to aid project teams in managing and delivering sustainable construction. BRE (2004) and the SueMOT project (Levett-Therivel, 2004) identified in excess of 600 tools related in some way to evaluating at least one of the 'three pillars', including distinct types of tool, urban planning, design, rating system, life-cycle analysis tools and infrastructure. Whereas it was found that nearly all these tools did address environmental issues, few addressed the holistic nature of sustainability, which also reflects the observations of Rydin et al. (2006). Of these tools, the Civil Engineering Environmental Quality Award and Assessment Method (Ceequal) (www.ceequal.com) is widely recognised as being the only definitive tool for the assessment of environmental impact due to infrastructure works (DTI, 2006; Levett-Therivel, 2004; Persi, 2005; Petus, 2006 ) and is the Breeam equivalent for infrastructure developed in the UK to reward projects that go beyond legal requirements and use best practice in civil engineering works (Petus, 2006). Although other tools are being developed, they are broadly based on Ceequal (Persi, 2005) or similar approaches (Ghumra et al., 2009). Ceequal does not take into account economic effects, but it does look at social and environmental dimensions through a weighted scoring system that requires qualitative and quantitative data to provide a numerical score upon completion (Petus, 2006). It does, however, have a number of drawbacks that have been recognised, which include it not addressing the holistic nature of sustainability and placing emphasis on environmental best practice. It is also seen as being 'shallow' in its coverage of community and economic issues (Levett-Therivel, 2004), although Ceequal has been revised recently to address some of these shortcomings.

\section{DISCUSSION: TOWARDS A UNIFIED CONVERSATION ON SUSTAINABILITY IN INFRASTRUCTURE PROJECTS}

Having established that sustainable infrastructure is a crosscutting concept that encompasses both planning policy and sustainable construction, it is appropriate to question whether the available assessment tools are really offering credible approaches for the civil engineer to use in developing sustainable projects. Reviewing the available guidance from a variety of sources including Ceequal, the Seeda checklist and others (BRE, 2009; Ceequal, 2008; CIBSE, 2007a; DBERR, 2007;

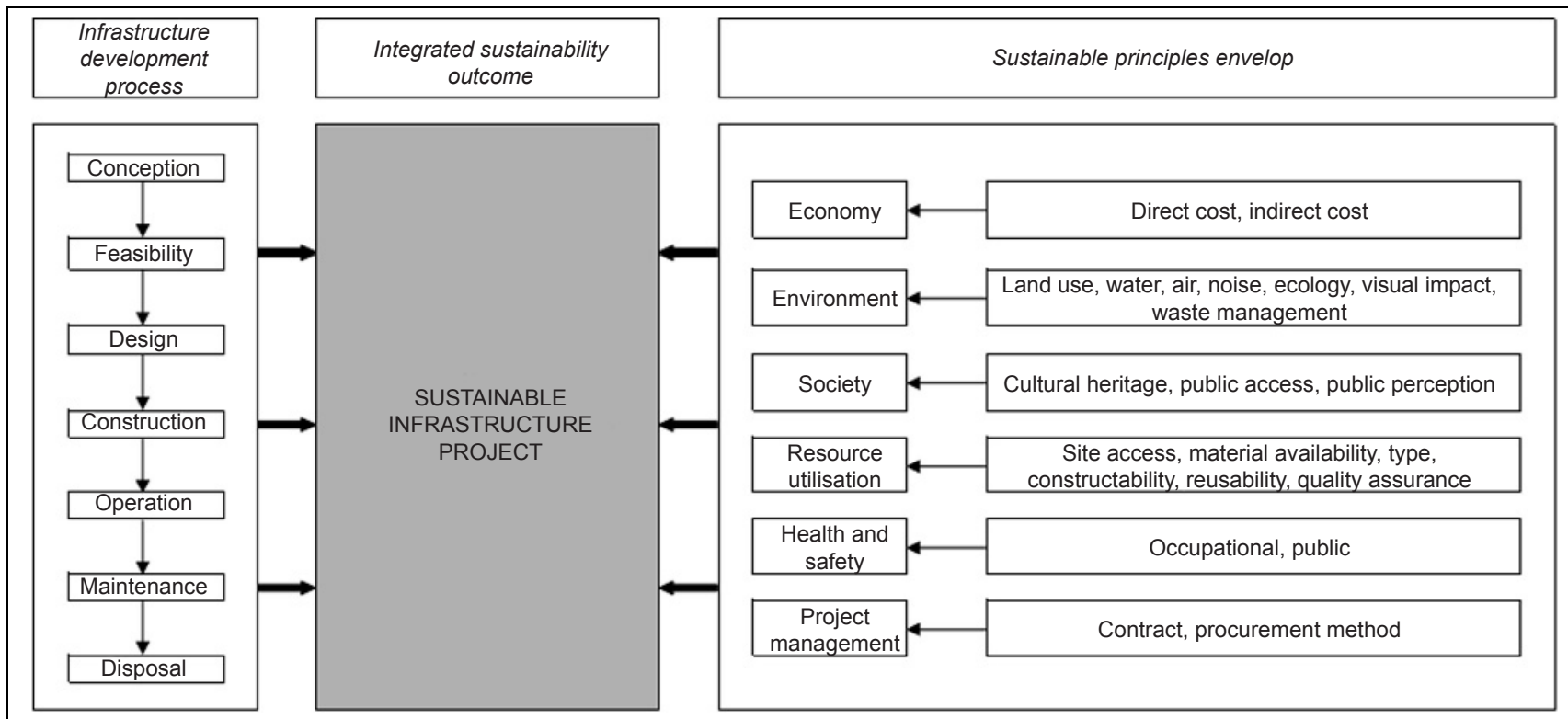

Figure I. Conceptual framework for a sustainable infrastructure project (Lim and Yang, 2006) 


\begin{tabular}{|c|c|c|c|c|c|c|}
\hline Document & $\begin{array}{c}\text { BRE checklist } \\
\text { for develop- } \\
\text { ment } \\
\text { (Brownhill and } \\
\text { Rao, 2002) }\end{array}$ & $\begin{array}{c}\text { Ceequal } \\
(2008)\end{array}$ & Seeda (2008) & $\begin{array}{c}\text { Sustainable } \\
\text { construction } \\
\text { strategy } \\
\text { (DBERR, } \\
2008)\end{array}$ & $\begin{array}{l}\text { Code for } \\
\text { Sustainable } \\
\text { Homes } \\
\text { (DCLG, } \\
\text { 2009) }\end{array}$ & $\begin{array}{c}\text { Breeam } \\
\text { Communities } \\
\text { (BRE, 2009) }\end{array}$ \\
\hline \multicolumn{7}{|l|}{ Policy } \\
\hline Energy and carbon dioxide & $x$ & $x$ & $x$ & $x$ & $x$ & $x$ \\
\hline Water & $x$ & $x$ & $x$ & $x$ & $\mathrm{X}$ & $x$ \\
\hline Waste & $x$ & $x$ & $x$ & $x$ & $x$ & $x$ \\
\hline Ecology & $\mathrm{x}$ & $x$ & $x$ & $x$ & $x$ & $x$ \\
\hline Land use & $x$ & $x$ & $x$ & & & $x$ \\
\hline Procurement & & $x$ & & & & \\
\hline Climate change & & $X$ & $X$ & $X$ & & $x$ \\
\hline Sustainable transport & $x$ & $x$ & $x$ & & & $x$ \\
\hline Health or wellbeing & & $x$ & & & $\mathrm{X}$ & \\
\hline Materials & & $x$ & $x$ & $x$ & $x$ & $x$ \\
\hline Management & & $x$ & & & $x$ & \\
\hline Resources & $x$ & $x$ & $x$ & & & $x$ \\
\hline Business & $x$ & & $x$ & $x$ & & $x$ \\
\hline Community & $x$ & $x$ & $x$ & & & $x$ \\
\hline
\end{tabular}

DCLG, 2009; Seeda, 2008), there appears to be a consensus on the key topics that civil engineers and planners both need to understand and consider when looking for solutions to deliver sustainable developments. A summary of these themes can be seen in Table 2.

Looking at these criteria it is clear that the same topics are recurring, most of which are considered by the assessment methods at various stages of the construction process from concept/pre-planning to construction and, in some cases, operation and maintenance. Built environment professionals are thus being asked to address the same themes, but are engaging with the issues at different stages of the construction process, which is far from ideal if a project is to deliver a sustainable outcome. While the planning system has (historically at least) not been the vehicle to deliver environmental protection explicitly, it does have the potential to mitigate environmental impacts significantly in the future and connect stakeholders through community engagement to raise environmental concerns (Manie, 2007). This is critical, for built assets are as important as infrastructure, which is one of the principal delivery mechanisms of the wider sustainability agenda through helping drive a nation's prosperity, public health, standard of living and competitiveness (Mirza, 2006), but it has been shown to cause impacts to the surroundings over many centuries (Boyle and Coates, 2005). Therefore, the sustainability of location, design, operation and maintenance should be considered at the earliest opportunity. If a development is to aspire to being sustainable then it is essential that this is considered from the inception, with engineers being involved at the point when there is the greatest likelihood of delivering the most beneficial solutions at the lowest cost (CIBSE, 2007a; Mayor of London, 2006). Failure to consider or engage suitable stakeholders regarding sustainability early on or treating it as an add-on to the design later on are among the most common reasons for projects to fail in the long term (Williams and Dair, 2007).

There is also a strong argument in the literature for built environment professionals to improve their sustainability literacy if they are to be able to maximise their potential to minimise the impact of new developments on future resources and generations as well as meet current legislative drivers (CIBSE, 2007b; Forum for the Future, 2000; The Royal Academy of Engineering, 2005). Whereas those engaged in the delivery of the built environment cannot be expected to, nor would it be desirable for them to attempt to be experts in the huge range of topics that are bannered under sustainability, there is a very clear case for them to have a far greater understanding and familiarity of the new environmental, social and economic issues that they may now encounter (Davidson et al., 2007). With this improved literacy should also come an increased awareness of the consequences of poor design, the correct time to engage other professions, stakeholders and the potential to frame success and/or performance of a project through its ability to minimise its impact on the planet and communities (Davidson et al., 2007; Forum for the Future, 2000; Murray and Cotgrave, 2007).

From this discussion, it is possible to identify four clear changes that are required to the current way of working on development projects such that these improvements can happen.

\section{I. Engineers need to have far greater involvement in the early engagement of stakeholders}

This is widely recognised as being essential for the successful delivery of projects that are sustainable on all levels (Engineering Council UK, 2009; Llewelyn-Davies, 2000). In their review of stakeholder influence on brownfield redevelopment, Williams and Dair (2006) found that most stakeholders aimed to pass minimum standards, such as building regulations, rather than surpass them and create sustainable projects. They also found that the timing of engaging stakeholders and the variety of those involved had a major impact, with many stakeholders simply not regarding sustainability as a measure of success due to a lack of knowledge and poor understanding of the technical issues.

\subsection{Engineers should use their technical skills to educate and influence decision makers}

For instance, when planners are engaging communities, engineers have an important role to play in providing 
technically feasible and innovative solutions to realise designers' visions, which can disenchant communities when it becomes apparent that the vision presented at pre-planning stage is very different from that which is delivered (Boyko et al., 2006). Engineers should also look to question the design brief and ask questions of stakeholders regarding ethical and environmental issues, rather than purely technical issues, in an effort to create a more holistic project and also fulfil their role as good citizens (Engineering Council UK, 2009; Forum for the Future, 2000; The Royal Academy of Engineering, 2005).

\subsection{Engineers need to be allowed to look beyond project/site-specific problems and begin to look at the larger issues and systems}

Often the infrastructure that is being developed is already limited in the solution that can be found by the constraints of a larger network, be it electricity distribution, highways or water, etc., which is reinforced by the assumption that these existing systems are sufficient and still relevant in a resourceconstrained and climate-changed future. Planners and policy makers should be engaging with engineers far more than is the current norm when it comes to discussing and setting medium to long-term local, district and regional strategies so that they can be based on technically feasible solutions while minimising their impact on future generations (Boyle and Donnelly, 2006; Fenner et al., 2006), although there are those who disagree, saying that engineers work in silos, dividing work into its smallest components, also citing past engineering blunders (Campbell, 2002; Cruickshank and Fenner, 2007; McCully, 1991).

\subsection{Planners and engineers should work more closely to develop indicators and benchmarks relating to the delivery of sustainable infrastructure}

While working together to create feasible and efficient growth and development plans, indicators and goals provide an effective way to drive and deliver a change in the way infrastructure is provided (Sahely et al., 2005). Now it is becoming clear that both parties have a common consensus on the issues that need to be tackled, it would make sense if common targets are developed. Although some planning authorities have been proactive in this area using supplementary planning documents to demand energy and water efficiency improvements, particularly in buildings (Pickvance, 2009), more can be done to ensure that the impact from infrastructure projects is minimised. However, it may never be desirable for planning authorities to set targets that are not feasible, yet based on sound engineering principles and judgement.

\section{CONCLUSIONS}

It is clear that the delivery of sustainability within infrastructure projects is not just about the cross-cutting industry themes of energy reduction, resource conservation, waste minimisation and climate change mitigation, etc., but is about a far wider and long-term commitment to create a better, healthier infrastructure to support society in the long term. Planning policy has been identified as one of the key mechanisms that have been tasked with the delivery of this ambitious ideal, but it is recognised that it can not deliver it alone. Whereas engineers have many of the skills and the potential to influence the wider agenda, in their current role they are not suitably positioned to maximise their impact. Engineers, planners and all professionals working in the built environment are going to be required to expand their knowledge of 'sustainable development' and adapt their role accordingly. Four recommendations have been made that the authors believe will allow engineers to have a greater impact on the future of sustainable construction by redefining their role to work more closely with planners and planning policy to allow for greater influence on the development of our built environment.

\section{ACKNOWLEDGEMENTS}

The study by the authors into sustainable infrastructure design and delivery receives contributory funding from the Engineering and Physical Sciences Research Council by means of the engineering doctorate scheme run from the Centre for Innovative and Collaborative Engineering at Loughborough University. The views expressed in this paper are solely those of the authors and not those of Jacobs Engineering.

\section{REFERENCES}

Adetunji IO and CICE (2006) Sustainable Construction. Centre for Innovative Construction Engineering (CICE), Department of Civil and Building Engineering, Loughborough University.

Bjorn A, Declercq-Lopez L, Spatari S and Maclean HL (2005) Decision support for sustainable development using a Canadian economic input-output life cycle assessment model. Canadian Journal of Civil Engineering 32(1): 16-29.

Boyko C, Cooper R, Davey C and Wooton A (2006) Addressing sustainability early in the urban design process. Management of Environmental Quality 17(6): 1477.

Boyle C and Coates GTK (2005) Sustainability principles and practice for engineers. Technology and Society Magazine, IEEE 24(3): 32-39.

Boyle C and Donnelly R (2006) The Catch-22 of engineering sustainable development. Journal of Environmental Engineering 132(2): 149-155.

BRE (Building Research Establishment) (2004) Assessment of Sustainability Tools. 15961. BRE, Glasgow.

BRE (Building Research Establishment) (2009) BREEAM Communities. See http://www.breeam.org/filelibrary/ BREEAM_Communities_-_Fact_Sheet_v2.pdf for further details (accessed 24/05/2009).

Brownhill D and Rao S (2002) A Sustainability Checklist for Developments: A Common Framework for Developers and Local Authorities. Building Research Establishment, Glasgow.

Campaign to Protect Rural England (2007) Deconstructing Barker. Levett-Therivel, London.

Campbell A (2002) The world summit on sustainable development: a view from an engineer. Ingenia 14: 59-61.

Ceequal (Civil Engineering Environmental Quality Award and Assessment Method) (2008) Scheme Description and Assessment Process Handbook. Responsible Solutions, Loughborough.

Chandler J, Reid J, Schiavi I et al. (2008) Sustainable Choice of Materials for Highway Works: A Guide for Local Authority Highway Engineers. The Stationery Office, London.

CIBSE (2007a) Sustainability. Guide L. CIBSE, London. CIBSE (2007b) Introduction to Climate Change. CIBSE, London. CIC (2007) Response to draft strategy for sustainable construction. See http://www.cic.org.uk/activities/consult.shtml for further details (accessed 08/02/2008).

CIOB (2007) Last update, response to the draft strategy for sustainable construction. See www.ciob.org.uk for further details (accessed 03/01/2008). 
Cole R (2005) Building environmental assessment methods: redefining intentions and roles. Building Research and Information 33(5): 255.

Cole R and Larson K (1999) GBC '98 and GB tool. Building Research and Information 27(4/5): 221-229.

Cooper I (2006) Sustainable Construction and Planning The Policy Agenda. CEPG, London.

Cruickshank HJ and Fenner RA (2007) The evolving role of engineers: towards sustainable development of the built environment. Journal of International Development 19(1): 111-121.

Davidson C, Matthews C, Hendrickson C et al. (2007) Adding sustainability to the engineer's toolbox: a challenge for engineering educators. Environmental Science and Technology 41(14): 4847-4849.

DBERR (Department of Business, Enterprise and Regulatory Reform) (2007) Draft Strategy for Sustainable Construction 2007: a Consultation Paper, DBERR, London.

DBERR (Department of Business, Enterprise and Regulatory Reform) (2008) Strategy for Sustainable Construction. DBERR, London.

DCLG (Department of Communities and Local Government) (2006) The Barker review of land use planning - planning, building and the environment. [Homepage of DCLG]. See http://www.communities.gov.uk/planningandbuilding/ planning/planningpolicyimplementation/reformplanningsystem/barkerreview/ for further details (accessed 07/02/ 2008).

DCLG (Department of Communities and Local Government) (2007a) Planning and Climate Change: Supplement to PPS1. DCLG, London.

DCLG (Department of Communities and Local Government) (2007b) White Paper: Planning for a Sustainable Future. DCLG, London.

DCLG (Department of Communities and Local Government) (2009) Code for Sustainable Homes: Technical Guide. DCLG, London.

DETR (Department of the Environment, Transport and the Regions) (2000) Building a Better Quality of Life: A Strategy for More Sustainable Construction. The Stationery Office, London.

DETR (Department of the Environment, Transport and the Regions) (2005) Securing the Future: Delivering UK Sustainable Development Strategy. The Stationery Office, London.

DfT (Department for Transport) (2006) The Eddington transport study. [Homepage of DfT]. See http://www.dft.gov.uk/about/ strategy/transportstrategy/eddingtonstudy/ for further details (accessed 07/02/2008).

DOE (Department of the Environment) (1994) Sustainable Development: The UK Strategy. CM 2426. HMSO, London.

DTI (Department of Trade and Industry) (2006) Review of Sustainable Construction 2006. DTI, London.

DTI (Department of Trade and Industry) and Faber Maunsell (2008) Practical sustainable design and construction for planners and developers. See http://www.sustainableconstruction.org.uk/ for further detail (accessed 07/02/2008).

Egan J (1998) Rethinking Construction: The Report of the Construction Task Force. Department for Environment, Trade and the Regions, London.

Egan J (2004) The Egan Review: Skills for Sustainable Communities. Department of Communities and Local
Government. See http://www.communities.gov.uk/ publications/communities/eganreview for further details (accessed 07/02/2008).

Elkington J (1994) Towards the sustainable corporation: winwin-win business strategies for sustainable development. California Management Review 36(2): 90-100.

Engineering Council UK (2009) Guidance on Sustainability for the Engineering Profession. See http://www.engc.org.uk/ documents/EC0018_SustainabilityGuide.pdf for further details (accessed 01/10/2009).

English Partnerships (2006) The Brownfield Guide. English Partnerships, London.

Fenner R, Ainger C, Cruickshank H and Guthrie P (2006) Widening engineering horizons: addressing the complexity of sustainable development. Proceedings of the Institution of Civil Engineers Engineering Sustainability 159(4): 145-154.

Forman RTT and Alexander LE (1998) Roads and their major ecological effects. Annual Review of Ecology and Systematics 29: 207-231.

Forum for the Future (2000) The Engineer of the 21st Century Enquiry. Forum for the Future, London.

Gambatese JA and Rajendran AS (2005) Sustainable roadway construction: Energy consumption and material water generation of roadways. Proceedings of the Construction Research Congress: Broadening Perspectives, ASCE, Reston, VA, pp. 102-108.

Ghumra S, Watkins M, Phillips P et al. (2009) Developing a LCAbased tool for infrastructure projects. In Proceedings of the 25th Annual Conference of Association of Researchers in Construction Management (ARCOM) (Dainty ARJ (ed.)). ARCOM, Nottingham, pp. 1003-1010.

Gunder M (2006) Sustainability: planning's saving grace or road to perdition? Journal of Planning Education and Research 26(2): 208-221.

Hartshorn J, Maher M, Crooks J, Stahi R and Bond Z (2005) Creative destruction: building toward sustainability. Canadian Journal of Civil Engineering 32(1): 170-180.

Hill R and Bowen PA (1997) Sustainable construction: principles and a framework for attainment. Construction Management and Economics 15(3): 223-239.

Huang RY and Yeh CH (2008) Development of an assessment framework for green highway construction. Journal of the Chinese Institute of Engineers 31(4): 573-585.

Kaatz E, Root D, Bowen P and Hill R (2006) Advancing key outcomes of sustainability building assessment. Building Research and Information 34(4): 308-320.

Kibert C (2007) The next generation of sustainable construction. Building Research and Information 35(6): 595-601.

Levett-Therivel (2004) Analysis of Sustainability/Social Tools. sue-MOT, Oxford.

Levett-Therivel (2007) Environmental Sustainability and English Regional Strategies. Report to CPRE, WWF-UK and FoE England, Oxford.

Lim SK and Yang J (2006) Understanding the need of project stakeholders for improving sustainability outcomes in infrastructure projects. Proceedings of Joint CIB Conference: Performance and Knowledge Management, Australia, pp. 333-343.

Lin ML (2005) Strategies and ecological engineering considerations of road construction in Taiwan. Journal of Ecotechnology 1(1): 9-28.

Llewelyn-Davies (2000) in association with Alan Baxter Associates. Urban design compendium. [Homepage of 
English Partnerships]. See http://www.urbandesigncompendium. co.uk/public/documents/UDC1FULL.pdf for further details (accessed 01/10/2007).

Manie B (2007) Construction, law and the environment: a historical review. Proceedings of the Institution of Civil Engineers Management, Procurement and Law 160(4): 169-177.

Mayor of London (2006) London's Urban Heat Island. Greater London Authority, London.

McCully P (1991) A case against climate aid. The Ecologist 21(6): 244-251.

Mirza S (2006) Durability and sustainability of infrastructure - a state of the art report. Canadian Journal of Civil Engineering 33(6): 639.

Murray P and Cotgrave A (2007) Sustainability literacy: the future paradigm for construction education? Structural Survey 25(1): 7-23.

ODPM (Office of the Deputy Prime Minister) (2003) Sustainable Communities: Building for the Future. ODPM, London.

ODPM (Office of the Deputy Prime Minister) (2005a) Planning Policy Statement 1: Delivering Sustainable Development. ODPM, London.

ODPM (Office of the Deputy Prime Minister) (2005b) A Practical Guide to the Strategic Environmental Assessment Directive. ODPM, London.

Parkin S, Sommer F and Uren S (2003) Sustainable development: understanding the concept and practical challenge. Proceedings of the Institution of Civil Engineers, Engineering Sustainability 156(1): 19-26, doi: 10.1680/ ensu.2010.156.1.19.

Pearce D (2006) Is the construction sector sustainable? Definitions and reflections. Building Research and Information 34(4): 201-207.

Persi (2005) Proposed plan for the assessment of knowledge and practice for sustainable infrastructure. See http://www.persi. us/documents/PlanProposedNA.doc for further details (accessed 08/02/2008).

Petus (2006) Practical evaluation tools for urban sustainability. See http://www.petus.eu.com/ for further details (accessed 08/02/2008).

Pickvance C (2009) The construction of UK sustainable housing policy and the role of pressure groups. Local Environment: The International Journal of Justice and Sustainability 14(4): 329-345.

Planning Act (2008) Elizabeth II. Chapter 29. Her Majesty's Stationary Office, London.

Planning and Compulsory Purchase Act (2004) Elizabeth II. Chapter 5. Her Majesty's Stationary Office, London.

Prior J and Williams C (2008) Delivering Sustainability Objectives through Planning. IP3/08. IHS. Building Research Establishment, Glasgow.
QPA (Quarry Products Association) (2007) Last update, response to the draft strategy for sustainable construction. See http://www.qpa.org/con_other01.htm for further details (accessed 08/02/2008).

Roberts C and Sims S (2007) Cashing in on the green machine: are developers missing out? Working paper in real estate and construction. International Journal of Housing Markets and Analysis 1(4): 362-378.

Rydin Y, Amjad U, Moore S et al. (2006) Sustainable Construction and Planning: The Academic Report. CEPG, London.

Sahely HR, Kennedy CA and Adams BJ (2005) Developing sustainability criteria for urban infrastructure systems. Canadian Journal of Civil Engineering 32(1): 7285.

Shah SS (2007) Sustainable Practice for the Facilities Manager. Blackwell, Oxford.

Seeda (South East England Development Agency) (2008) Sustainability checklist. See http://southeast.sustainabilitychecklist.co.uk/ for further details (accessed 20/06/2009).

SDRN (Sustainable Development Research Network) (2008) Issues for the Practice of Sustainability Appraisal in Spatial Planning - a Review. Land Use Consultants and The Royal Town Planning Institute, London.

The Royal Academy of Engineering (2005) Engineering for Sustainable Development: Guiding Principles. The Royal Academy of Engineering, London.

Ugwu 00 and Haupt TC (2005) Key performance indicators and assessment methods for infrastructure sustainability - a South African construction industry perspective. Building and Environment 42(2): 665-680.

WCED (World Commission on Environment and Development) and Brundtland GH (1987) Our Common Future. Oxford University Press, Oxford.

Williams K (2006) Pioneering research asks whether planning can realise sustainability. Planning November.

Williams K and Dair C (2006) Sustainable land reuse: the influence of different stakeholders in achieving sustainable brownfield developments in England. Environment and Planning A 38(7): 1345-1366.

Williams K and Dair C (2007) What is stopping sustainable building in England? Barriers experienced by stakeholders in delivering sustainable development. Sustainable Development 15(3): 135-147.

Wyatt DP (1994) Recycling and serviceability: the twin approach to securing sustainable construction. In Proceedings of the First International Conference of $C I B$ TG16 on Sustainable Construction (Kibert CJ (ed.)). University of Florida, Gainesville. USA.

\section{What do you think?}

To discuss this paper, please email up to 500 words to the editor at journals@ice.org.uk. Your contribution will be forwarded to the author(s) for a reply and, if considered appropriate by the editorial panel, will be published as discussion in a future issue of the journal.

Proceedings journals rely entirely on contributions sent in by civil engineering professionals, academics and students. Papers should be 2000-5000 words long (briefing papers should be 1000-2000 words long), with adequate illustrations and references. You can submit your paper online via www.icevirtuallibrary.com/content/journals, where you will also find detailed author guidelines. 